\title{
Institutional Religious Accommodation in the US and Europe
}

\section{Comparative Reflections from a Liberal Perspective}

\author{
Patrick Loobuyck
}

\section{Introduction}

As a liberal political philosopher, I agree with Jean Cohen that the US jurisprudence about institutional accommodation is problematic. Especially in Hobby Lobby, the decision of the Supreme Court is unfair because it clearly defends group rights above and at the expense of individual freedom and equality rights. Cohen rightly points out that justice and the liberal concept of freedom of consciousness cannot do this work: what does the work is a medieval political-theological conception of church immunity and sovereignty. The Hosanna-Tabor case is more complicated. As far as Cheryl Perich was indeed employed as a 'minister' (also teaching some nonreligious courses), the evangelical Lutheran school has, in principle, more autonomy to decide about her employment. However, the fact that Perich is dismissed on other grounds than religious criteria (disability), while this criterion cannot be used by other (nonreligious) organizations, makes that Cohen's critique on the Supreme Court judgement is sound.

The first part of this article sketches how the autonomy of churches and religious associations can be considered from a liberal perspective, avoiding the pitfall of the medieval idea of libertas ecclesiae, which makes churches immune from politics. The second part illustrates that the European jurisprudence is more in line with liberalism than the US jurisprudence. Despite the fact that the European case law acknowledges some specific rights for churches and religious/expressive associations and employers, it would be surprising if the European Court were to rule in the same way as the US Supreme Court did in Hobby Lobby and HosannaTabor.

\section{A liberal perspective on the autonomy of (religious) associations}

\subsection{Church autonomy}

Liberals should make room for the idea of church autonomy, but only as a derivative of the individual freedom of conscience and association. Because these freedoms would be an empty box without the right to the collective experience of faith and worship, individuals have the right to organize themselves in churches 
and faith communities. ${ }^{1}$ Therefore, the separation of Church and State guarantees that faith communities are free to make their own decisions regarding structure, orthodoxy, ministers, and membership.

But this idea of church autonomy should be broadened in two directions. Firstly, the consequences of the freedom of association should be equal for religious and non-religious people/groups. If we agree, as we do, with Cohen and others ${ }^{2}$ that religion is not a unique category, there should not be other rules for faith-based associations than for associations based on secular values, ecology, sports, fair trade, etc. The use of religion as a special category does not only create a problem of inequality, there is also the problem of deciding what counts as a religion and what does not. ${ }^{3}$ Secondly, the discussion about religious group autonomy should not be limited to churches. Religious people also have the right to organize themselves around other activities based on their faith like education, health care, sports, youth movements, labour unions, adoption agencies, and business corporations.

\subsection{Group autonomy}

As a consequence, liberals should start from the general concept of group autonomy which implies that groups can use their own rules and criteria for admission, for membership, and for certain functions. People are free to establish associations only accessible to certain people with certain beliefs or certain characteristics. As long as they are private organizations, they are free to admit only men or women, or to stipulate that the president of the organization should be a man, a vegetarian, or a Catholic. And they may operate according to non-democratic rules, adopt a certain hierarchy, and restrict the freedom of their members in a variety of ways. Private associations, and thus also churches, should not mirror the principles of liberalism as long as they comply with certain conditions. Firstly, membership should always be voluntary. No coercion or intimidation

1 Rex Ahdar and Ian Leigh, Religious Freedom in the Liberal State (Oxford: Oxford University Press, 2013), 377.

2 Patrick Loobuyck, 'Critical Remarks on the Pro-religion Apriority of the RELIGARE Project', in Belief, Law and Politics: What Future for a Secular Europe? eds. Marie-Claire Foblets, et al. (Farnham/Burlington: Ashgate, 2014), 227-36; Brian Leiter, Why Tolerate Religion (Princeton: Princeton University Press, 2012); Steven D. Smith, 'Discourse in the Dusk: The Twilight of Religious Freedom?' Harvard Law Review 122(7) (2009): 1869-908; Christopher L. Eisgruber and Lawrence G. Sager, Religious Freedom and the Constitution (Cambridge: Harvard University Press, 2007); James Nickel, 'Who Needs Freedom of Religion', University of Colorado Law Review 76 (2005): 941-64.

3 Ahdar and Leigh, Religious Freedom, 139-55; Kent Greenawalt, Religion and the Constitution. Volume 1 (Princeton: Princeton University Press, 2009), 124-56.

This problem comes also to the fore when non-religious associations try to become accepted as a religious association in order to get more liberties. E.g., in February 2015, Indiana's First Church of Cannabis - a religious group that embraces marijuana use as a sacrament - has received the classification of a religious organization and consequently received the tax-exemption status. See also Jogchum Vrielink, 'Defining and Divining Religion', 22 November 2012 - about the 'smokers church' and 'the satanic sisters'. <http://strasbourgobservers.com/2012/11/22/defining-anddivining-religion/>. 
should be exercised; before and during the membership people should be free to consider alternatives (a ban on good education should therefore not be allowed); the group should give transparent information about its customs, practices, and expectations; and when people change their mind, the group must always leave open a realistic exit option.

Secondly, there is the difference between internal rules, values, and principles and the public rules based on freedom and equality. Although women/atheists/ black people may be excluded from membership or certain internal functions, there is a problem when the organization calls for active discrimination against women/atheists/black people. There is greater leeway with regard to internal members than there is with regard to external parties. In an ideal liberal situation, associations may restrict the freedom of their members, but they should not call for compromising the freedom and equality of non-members. Churches can argue that for their members contraception, euthanasia or same-sex marriage are sins and forbidden, but they should accept that the state cannot discriminate homosexuals in its legislation about marriage, and they should accept that nonmembers have different opinions about the use of contraception and their endof-life choices. Of course, this ideal of civic virtue imposes only a moral and not a legal duty, for in that case it would be incompatible with the freedom of speech of churches and other (non-liberal) groups.

\subsection{Employers}

The issue becomes more complicated when churches and religious associations become employers and/or organize some services like health care and education. When this kind of associations ask for accommodation based on their religious identity, the default position should be that they do not have more privileges than other (similar) associations. They have to pay the same taxes, offer the same working conditions, and have to respect the rule of law. They have a right to protect their own identity, but not at the expense of the demands of justice, freedom, and equal citizenship. In the case of employment, discrimination should be avoided as long as possible. Employment is a scarce commodity, and therefore jobs should be open for as many candidates as possible. This does not imply that religion and belief can never be used as a criterion, but they should only be part of a job requirement if that is necessary. Just like a football, trainer needs some knowledge about football and sport, a gardener about plants and gardens, and the actor who has to play Obama or Malcolm X in a movie should be black, it is a normal job requirement for the teacher of a confessional religious course to be an adherent of that religion. I agree with the European Commission that it is evident 'that in organizations which promote certain religious values, certain jobs or occupations need to be performed by employees who share the relevant religious opinion'. Religious-ethos employers are thus allowed 'to require occupational qualifications which are necessary for the fulfilment of the duties attached to the 
relevant post'. ${ }^{4}$ But all the other jobs should be as much as possible open for candidates with all kinds of religious or ideological backgrounds - especially in a context where there is a scarcity of job opportunities (for some groups). As a consequence, employers are not to be permitted to hire only persons who share the same (religious) beliefs. At most, the religious employer can ask some loyalty of the employees during the working hours towards the values and the religiously inspired project behind the non- or for-profit organization. With reference to the British Equality Act of 2010, Peter Jones writes: 'there is no problem in a church's discriminating on religious grounds in its appointment of a priest or in a mosque's doing so in its appointment of an imam, although there may well be a problem if either takes account of an applicant's faith when it appoints a gardener or a cleaner or an accountant'. ${ }^{5}$ This distinction is a legitimate starting point.

Can a religious-based (non-)profit organization use selective criteria for offering their services? This question is not discussed by Cohen, but we can suppose that she would be reluctant to give religious organizations more possibilities for discrimination than other organizations. Of course churches can refuse membership and services towards people who do not share the same religion or beliefs. And the same is true for private schools paid for by the parents who share the same religion or belief. But in almost all other situations and (outward-looking) initiatives taken by churches and religious individuals and organizations - especially for-profit initiatives where employees with different religious identities work for the profit of the employer - they should not have the same right for discrimination. ${ }^{6}$ That bed-and-breakfasts or bakeries are not allowed to refuse same-sex couples or Jews, cannot be overruled by the fact that the owners of the bed-andbreakfasts or bakeries are religious.

\subsection{Freedom of religion?}

From this liberal perspective, it is difficult to defend the two US Supreme Court decisions. The Court used the controversial rule-and-exemption approach to discharge a religious association from a generally applicable (tax/anti-discrimination) law. This approach is controversial because it is a threat to the principle of equality; only in extraordinary cases is it useful to apply the rule-and-exemption approach. ${ }^{7}$ These involve situations in which enforcing the generally applicable law is desirable for pragmatic (rather than moral) reasons - e.g., Sunday closing legislation - and in which granting an exception would enhance freedom without placing anyone else at a disadvantage. Tax and anti-discrimination law, however,

4 Proposal for a Council Directive establishing a general framework for equal treatment in employment and occupation, 25 November 1999, COM (1999) 565 final, Explanatory memorandum, 10.

5 Peter Jones, 'Toleration, Religion and Accommodation', European Journal of Philosophy (2012) doi: 10.1111/j.1468-0378.2012.00549.x

6 For the idea that inward-looking activities give more reasons for exceptions in non-discrimination law than outward-looking activities, see Shelley Wessels, 'The Collision of Religious Exercise and Governmental Non-discrimination Policies', Stanford Law Review 41 (1989): 1201.

7 Brian Barry, Culture and Equality. An Egalitarian Critique of Multiculturalism (Cambridge: Polity, 2001), 39; Loobuyck, 'Critical Remarks', 233-34. 
are not based on pragmatic considerations, but on reasons of justice and equality. Exemptions should not be allowed here.

In addition to Jean Cohen's considerations about sovereignty, I would like to present another argument against the super-autonomy and the self-government rights claimed by some religious associations. ${ }^{8}$ Except for the churches themselves, privately funded religious schools and religious jobs, religious and other kinds of discrimination and exemptions form democratic law should not be allowed for religious organizations because these restrictions do not interfere with the freedom of religion at all. In Hobby Lobby, the Court invokes a dilemma between the judicial protection of religious liberty and the benefits of operating as a corporation. But that is a false dilemma. Compare it with Brian Barry's critique on the exemptions for the Sikhs to the obligation of wearing a crash helmet on the motorcycle: firstly, nobody is bound to ride a motorcycle, and secondly, the Sikhs are prevented from riding a motor cycle not because of the English law, but by the requirements of their religion. ${ }^{9}$ The same is true for religious-based profit organizations and many (maybe not all) non-profit organizations. Firstly, nobody is bound to start his or her own business corporation or non-profit organization. There is nothing in religion that requires its adherents to organize that kind of economic activities. Secondly, the tax and discrimination laws do not prevent the organization of economic and social services but the requirements of their religion. Churches and religious-based organizations have the right to establish all kinds of economic and social activities, but since they do that in a society with particular democratic rules aimed to establish and to protect justice, freedom, and equality, they should comply with these general (taxation) rules and legal duties. If not, they do not deserve exemptions but should decide to renounce their plans and activities.

\subsection{Activities paid for by the government}

Finally, a reflection about situations in which the religious-based (non-profit) associations receive financial state support for organizing their activities and services. Privately funded Catholic hospitals or Jewish schools have more right to discriminate in their policies regarding admission and employment, than Catholic hospitals and Jewish schools which are (partially) funded by the government. The argument is that institutions that provide general social services for which everyone pays through taxes should also be accessible to everyone - in terms of patients or students as well as physicians or teachers.

So, publicly funded hospitals and schools should not be permitted to refuse doctors, regular teachers, patients, or students for ideological reasons. Questions concerning religious or ecclesiastical involvement during job interviews with physicians or nursing staff are therefore inappropriate. And in the case of a pub-

8 For further discussion about institutional exemptions as 'partial self-government rights' for religious institutions, see Andrew Shorten, 'Are There Rights to Institutional Exemptions', Journal of Social Philosophy 46(2) (2015): 242-63.

9 Barry, Culture and Equality, 44-45. 
licly funded Catholic school, it should be possible to restrict religious discrimination to teachers of Catholic religion, given that the requirement to be Catholic stems from the nature of the job itself. From the perspective of the Catholic school, it is understandable that they would prefer to have a Catholic mathematics teacher (because this could contribute to the school's religious identity, even outside of class). From the perspective of non-Catholic mathematics teachers, however, it would be unfair to deny them employment in schools that are funded by everyone. This problem becomes even more important when Catholic schools or hospitals have a large share of the market. All of this does not mean that schools should give up their project all together. Pupils and teachers in a subsidized school that promotes vegetarianism or Catholicism should not be Catholic or vegetarian but can be asked not to eat meat in school or to respect the Catholic project of the school.

Governments can also use the financial support as an incentive: the more schools, hospitals, and other associations based on religion or belief are open for everyone, the more they can receive public financial support. It is not yet a common practice in all of the European countries, but conditioning the receipt of government funds on internal practices that match public values is possible within a liberal framework. ${ }^{10}$ The freedom of religion and the separation of Church and State do not prevent states from using financial incentives to stimulate religious (and other) actors to accept openness, inclusiveness and liberal democracy as the overall framework for their activities. Moreover, this idea of what Rik Torfs has called 'contractual religious freedom' or 'conditional subsidies' can also be used towards religions and church communities: 'the state supports religious groups materially, and in exchange the religious group agrees not to exercise all aspects of religious freedom'. ${ }^{11}$ For instance, the price for official recognition and public support could be the religious group's acceptance of inclusiveness, non-discrimination and the democratic rule of law as a general framework within which the church and their religious associations ought to operate.

\section{A European perspective}

\subsection{Legal framework}

Article 9 of the European Convention on Human Rights (ECHR) protects 'the right to freedom of thought, conscience, and religion', including the freedom 'either alone or in community with others and in public or private, to manifest his religion or belief, in worship, teaching, practice and observance' (my italics). The second clause of Article 9 subjects this freedom 'to such limitations as are pre-

10 Stephen Macedo, 'Constituting Civil Society: School Vouchers, Religious Nonprofit Organizations, and Liberal Public Values', Chicago-Kent Law Review 75 (2000): 432, 440-442 and Stephen Macedo, 'The Constitution, Civic Virtue, and Civil Society: Social Capital as Substantive Morality', Fordham Law Review 69 (2001): 1591-93.

11 Rik Torfs, 'Muslims in Belgium', in Islam and Political Cultural Europe, eds. W. Cole Durham, David Kirkham and Tore Lindholm (Farnham: Ashgate, 2012), 84-85. 
scribed by law and are necessary in a democratic society in the interests of public safety, for the protection of public order, health, or morals, or the protection of the rights and freedoms of others'.

Article 11 protects the freedom of association and safeguards associative life against unjustified state interference. When Article 9 is interpreted in the light of Article 11 we end up with church autonomy. In the words of the European Court of Human Rights (ECtHR): 'Were the organizational life of the [religious] community not protected by Article 9 of the Convention, all other aspects of the individual's freedom of religion would become vulnerable'. ${ }^{12}$ Also many European countries have constitutional guarantees (e.g., Belgium and Germany) or other regulations (e.g., United Kingdom Human Rights Act) recognizing church autonomy. ${ }^{13}$

For our discussion, also Article 14 is relevant. The article prohibits 'discrimination on any ground such as sex, race, colour, language, religion, political or other opinion, national or social origin, association with a national minority, property, birth, or other status'. Also the Employment Equality Directive (2000) 'establishing a general framework for equal treatment in employment and occupation' protects against discrimination on a number of grounds and provides extensive protection of religious interests in the European workplace. Yet, in Europe the law does not provide a straightforward obligation to accommodate religious claims at work similar to the duty of reasonable accommodation of religious needs of workers which has been recognized in the United States and in Canada. There is a discussion going on about the need to make it a juridical obligation, ${ }^{14}$ but meanwhile accommodation in the European work place has been provided by many employers $^{15}$ and the jurisdiction of the European Court shows that employers cannot simply discriminate against (candidate) employers with religious symbols. ${ }^{16}$

\subsection{Religion as a special category}

In general, religion is not so much used as a special and unique category in Europe as it is the case in the United States. The European system lacks an establishment

Hasan and Chaush v. Bulgaria (2000) [62]. See also Supreme Holy Council of the Muslim Community v. Bulgaria, 2004 [74] and X v. Denmark 1972.

13 Gerhard Robbers (ed.), Church Autonomy: A Comparative Survey (Frankfurt: Peter Lang, 2001).

14 Katayoun Alidadi, Marie-Claire Foblets and Jogchum Vrielink (eds.), A Test of Faith? Religious Diversity and Accommodation in the European Workplace (Farnham: Ashgate, 2012); Katayoun Alidadi, 'Redelijke aanpassingen voor religieuze praktijken op de Belgische werkvloer: van "goodwill" naar afdwingbaar recht?' in Les Assises de l'Interculturalité: Regards Croisés/De Rondetafels van de Interculturaliteit: een Terugblik, eds. Marie-Claire Foblets and Jean-Philippe Schreiber (Brussels: Larcier, 2013), 301-42.

15 Ilke Adame and Andre Rea (eds.), Culturele Diversiteit op de Werkvloer. Praktijken van Redelijke Aanpassing in België (Brussel: Centrum voor Gelijke Kansen en voor Racismebestrijding, 2010).

16 See Eweida and Others v. the United Kingdom (27 May 2013) where the Court argues that British airways should allow Ms. Eweida to wear a discreet cross to manifest her religious belief at work. See also Veit Bader, Katayoun Alidadi and Floris Vermeulen, 'Religious Diversity and Reasonable Accommodation in the Workplace in Six European Countries: An Introduction', International Journal of Discrimination and the Law, 13(2-3) (2013): 54-82. 
clause and Europe has no such a thing as the Religious Freedom Restoration Act (RFRA) that guarantees extra and special protection for religious freedom on the individual and on the collective level. But still, religion and religious freedom are often mentioned separately in European juridical texts, and that may suggest that also in Europe religious freedom and religious associations get some special protection. A well-known example is the European Council Directive 93/119/EC of 22 December 1993 'on the protection of animals at the time of slaughter or killing' that protects the exemption of ritual slaughter.

However, also the Employment Equality Directive provides a specific exception for religious-ethos employers. ${ }^{17}$ Article 4.2 stipulates that 'churches and other public or private organizations the ethos of which is based on religion or belief are exempted from the ban on religious discrimination when "by reason of the nature of these activities or of the context in which they are carried out, a person's religion or belief constitute[s] a genuine, legitimate and justified occupational requirement, having regard to the organization's ethos' ${ }^{18}$

The Directive makes the relevant distinction between jobs that are directly related to the preservation and dissemination of the association's ideological or religious identity and other jobs that can be done without any interference with its religion and beliefs. With regards to the latter, the second section of Article 4.2 only stipulates that "churches and other public or private organizations, the ethos of which is based on religion or belief, acting in conformity with national constitutions and laws', have the right 'to require individuals working for them to act in good faith and with loyalty to the organization's ethos'. This distinction suggests that the possibility of religious-based employers to discriminate is more limited in Europe than in the United States were, as Cohen has mentioned and the Amos case (1987) has illustrated, the 1972 amendment of section 702 of the Civil Rights Act dropped the requirement that religious organizations may discriminate on the basis of religion only in relation to their religious activities.

The European Directive contains, however, several difficulties. Firstly, the distinction between the employees whose roles are directly religious in nature and the other jobs is a matter of interpretation. The difference between the priest and the church cleaner is clear, but in which category are the teachers in religious schools or the doctors and nurses in hospitals run by religious foundations? Moreover Article 4.2 mentions not only 'the nature of these activities' but also 'the context in which they are carried out' as a reason for discrimination. According to Olivier De Schutter, that opens the door for a more collective approach in which every employee can be considered as a member of a broader (religious based) community. In that interpretation, all the employees should share the

17 Yves Stox, 'Religious-ethos Employers and Other Expressive Employers Under European and Belgian Employment Law', in A Test of Faith?, eds. Katayoun, Foblets, and Vrielink, 151-78.

18 See also Article 13 of the Belgian anti-discrimination law of 2007. 
same religion as the religious-ethos based employers... ${ }^{19}$ Secondly, it is not clear what loyalty means: is it a necessary attitude during the working hours or does it also have repercussions for the freedom of speech outside the context of work? Can a physician be fired because he argued in favour of abortion while he is working for a Catholic hospital ${ }^{20}$, and can a Christian nursery worker be dismissed after telling a lesbian colleague her gay lifestyle was a $\sin ?^{21}$ Is the extra-marital sexual relationship of the organist of the church relevant and can it be seen as disloyalty toward the church/employer? ${ }^{22}$

Thirdly, what should happen when the requirement to adhere to a particular religion involves discrimination on other grounds? Could a religiously run hospital or school which requires senior staff to be Catholic also require not to be divorced and not to be in a homosexual relationship? ${ }^{23}$

Fourthly, there is the question whether 'neutrality' can constitute a particular company identity in order to justify a ban on headscarves and other religious symbols. ${ }^{24}$ Finally, it is not clear why the Directive has a separate regulation (4.2) for religious-based associations because Article 4.1 already contains the idea that a religious characteristic is a genuine and determining occupational requirement provided that the objective is legitimate and the requirement is proportionate. Not only employers with a religious ethos seek to realize a particular identity beyond the general commercial goal-setting. There are employers intending to maintain, develop, and disperse a particular philosophical, religious, moral, ecological, charitable, or other set of thoughts or beliefs. One of the main goals of these so-called 'expressive employers' is to express their values and 'philosophy of life' and that may imply some contractual restrictions for the employees concerning loyalty and respect for the company's image, brand, and values. Religiousethos employers are just one category of these expressive employers. As such, it was not necessary for the Directive to give special attention to them in Article 4.2 since they were already included in Article 4.1.

\subsection{Autonomy of religious-based associations in Europe and the US}

Going back now to the accommodation claims mentioned in Cohen's article and the question whether there are similar claims in the European context. Hobby Lobby and the RFRA that was used in that case have no equivalent in Europe. The European legal context and tradition make it also improbable that the national and European courts would agree with the idea that a for-profit corporation can escape regular taxation rules for religious reasons. Expressive and religious-ethos

21 Cf. 'Christian Nursery Worker Sacked Over Anti-gay Views Wins Tribunal Case', TheGuardian.com 7 June 2015.

22 Cf. infra Schütz v. Germany (2010).

23 Lucy Vickers, 'Religious Interests in the European Workplace: Different Perspectives', in A Test of Faith?, eds. Katayoun, Foblets, and Vrielink, 19.

24 Loobuyck, 'Critical Remarks'; Stox, 'Religious-ethos Employers', 153. 
employers have some rights to use special (religious) requirements for certain jobs, but that identity cannot be used for other exemption and accommodation claims. As far as I can see, democratic state sovereignty is not under pressure here. But Europe has to be careful because the shift towards this kind of institutional accommodation based on an idea of corporative immunity but sold by the argument of religious freedom is recognizable in the case of, for instance, Catholic hospitals that refuse to comply with euthanasia laws or in the case of Jewish schools that use the freedom of religion to censor important scientific information and moral thoughts.

The Hosanna-Tabor case is different because here it is not the (religious) associations that went to the Court for special treatment, but a dismissed employee with a complaint of discrimination. Some church employment disputes decided by the European Court seems to be similar in the sense that the Court had to balance individual and collective rights in the framework of the ECHR and the Employment Equality Directive. In Fernandez Martinez v. Spain (2012), the Court approved the dismissal of a religious education teacher with dissident ethical and religious opinions. The Court argued that it would be unreasonable if religious beliefs were not taken into account in the selection process, on the basis of guaranteeing the right of freedom of religion in its collective dimension'.

But there are also more complicated cases. The case Rommelfanger v. Germany (1989), for instance, in which the European Court permitted a Catholic private hospital in Germany to discharge a physician who had expressed public disagreement with the Church's stand on abortion. Or Siebenhaar v. Germany (2011): Mrs. Siebenhaar was dismissed from her job in a day care centre run by the protestant church because of her involvement in teaching catechism classes of another religion. And also here, the Court gave priority to the rights of the church. You can debate whether or not the Court took the right decisions, but what makes these cases still less problematic than Hosanna-Tabor, is that the Court took only the religious freedom and identity of the employer into consideration, while in Hosanna-Tabor employment discrimination was approved on other grounds, namely disability.

While the US Supreme Court seems to have gone for a more categorical approach, the ECtHR uses a 'weighing and balancing approach', using a proportionality test and taking the nature of the job and the situation of the applicant into considera- 
tion. ${ }^{25}$ As a consequence, the approach of ECtHR creates less foreseeability, but allows for greater flexibility. If the Court deems, for instance, that the defendant has sufficient opportunities for employment elsewhere, the employer has more right to be selective and to discriminate according to ideology.

That is one of the reasons why the Court decided differently in two similar cases: Obst v. Germany (2010) and Schüth v. Germany (2010). Obst was the Director of European public relations for the Mormon Church, Schüth was organist in a Catholic church. Both were dismissed because they had an extra-marital sexual relationship and both cases were dealt with under Article 8 (privacy and family life). The Court found the dismissal of Obst reasonable, but took another decision about Schüth. The Court acknowledged that a Church may impose a duty of loyalty upon its employees, but argued that also other relevant interests must be taken into account. According to the Court, it would be difficult for Schüth to find a new job outside the Church and the Court concluded that the rights of the applicant and those of the church-employer should be balanced in favour of the former.

\section{Conclusion}

Jean Cohen's paper reveals an important evolution in the logic of accommodation. Despite their differences, both exemplary cases illustrate that religious associations in the United States enjoy special treatment and can be exempted from general democratic rules based on freedom, equality, and justice. This evolution is against liberalism and is based on an inappropriate respect for church autonomy with roots in pre-modern political theological doctrines of church sovereignty.

This radical shift is not yet present in the European case law, which makes the European decisions on these issues until now more in line with liberalism. ${ }^{26}$ Cohen's argument is, however, also relevant for the European context: liberal democracy and pluralism are not based on the existence of corporative autonomous groups, but on freedom, equality, reciprocity, and justice. Also Europe should be aware that religious autonomy and immunity claims dressed up as lib-

Carolyn Evans and Anna Hood, 'Religious Autonomy and Labor Law: A Comparison of the Jurisprudence of the United States and the European Court of Human Rights', Oxford Journal of Law and Religion 1(1) (2012): 1-27; Mauto Gatti, 'Autonomy of Religious Organisations in the ECHR and EU Law', in Fundamental Rights in Europe and China Between Identities and Universalism, eds. Lucia Serena Rossi and Giacomo di Federico (Naples: Editoriale Scientifica, 2013), 132-53; Ian Leigh, 'Balancing Religious Autonomy and Other Human Rights under the European Convention', Oxford Journal of Law and Religion 1(1) (2012): 109-25; Saila Ouald Chaib, 'Religious Accommodation in the Workplace: Improving the Legal Reasoning of the European Court of Human Rights', in A Test of Faith?, eds. Katayoun, Foblets, and Vrielink, 52-54; Stox, 'Religious-ethos Employers', 174-8.

26 This evaluation is not necessarily true for the jurisprudence on individual accommodation issues and the freedom of conscience in general. See Martha C. Nussbaum, Liberty of Conscience: In Defence of America's Tradition of Religious Equality (New York: Basic Books, 2008), 13-14, 25, $348 f f$. 
eral claims in terms of freedom of association and freedom of religion, are dangerous wolves in sheep's clothing. 